KAIROS ELT JOURNAL, Vol. 2, No. 2, August 2018

Copyright $\odot 2018$, ISSN: 2580-4278

\title{
IMPROVING STUDENTS' VOCABULARY MASTERY THROUGH CROSSWORD PUZZLE GAME TO THE EIGHTH GRADE STUDENTS OF SMP SWASTA DHARMA BAKTI MEDAN
}

\author{
Unita Manullang, Viator Lumban Raja, Anna Stasya Prima Sari \\ Catholic University of Saint Thomas
}

\begin{abstract}
This research is aimed to improve students' vocabulary mastery through the application of crossword puzzle game. The subject of this research of the eighth grade students of SMP Swasta Dharma Bakti Medan. This research was conducted by applying Classroom Action Research (CAR) which was performed in two cycles (cycle I and cycle II) and each cycle consisted of three meetings. This instrument of collecting data are quantitative (vocabulary test) data and qualitative data (diary notes, observation sheet and photograph evidences).the result of vocabulary test as the quantitative data show that mean of students' score increased continuously from pre-test 36,71 , post-test in cycle I 64.10 , to post-test cycle II 78,48 . The diary notes, observation sheet and photograph evidences as qualitative data showed that the teaching and learning process ran well. It was found that crossword puzzle game could improve students' vocabulary mastery. It is suggested that teachers of English should apply crossword puzzle game as one of the game in teaching vocabulary mastery.
\end{abstract}

Keywords: Vocabulary, Crossword Puzzle

\section{INTRODUCTION}

Vocabulary is one of the language components which are quite decisive because without vocabulary people speak limitedly. In order to be able to communicate adequately, someone should have a stock of vocabulary. Communication will not flow if one has only a small number of vocabularies. Therefore, it is obligatory for him to develop his vocabulary for a better communication.

Teaching English to the students can be said tricky. Many people argue that to describe the subject matter is very difficult because in Indonesia, English is a foreign language which is taught in Elementary Schools, Junior High Schools, and Senior High Schools. For many years ago the material of English is emphasized in the structure of language. The students are expected to be able to recall the pattern of tenses. It is too hard for the students and it makes the students lazy to learn English. Besides that, the students are unable to speak English because of insufficient stock of vocabulary.

Teaching English as a foreign language is not the same as teaching English as a second language. Teaching English as a foreign language mean teaching the students in the target language in order to make them able to use the English language for communication. However, environment does not help the students in learning the English language. The learners do not use English outside of the classroom. They just use English when they have an English class. Consequently, the learners do not have many opportunities to practise English in their daily activities.

Learning and teaching English as a foreign language need the real situation to support the learners to use English naturally. The teacher should bring the real situation in the classroom by giving activities that support students to practise English. The teacher should create the technique of teaching English based on the real situation that the students can apply and practise the language freely and naturally. 
KAIROS ELT JOURNAL, Vol. 2, No. 2, August 2018

Copyright $\odot 2018$, ISSN: 2580-4278

Teaching vocabulary has such an important role in teaching English as a foreign language in classrooms, and it should therefore be part of the syllabus and taught on regular base. Any foreign language learner is always in need to learn and enrich his vocabulary. Beginners often manage to communicate in English by using individual words and they do not know how to convey meaning without necessarily having acquired grammar but at the same time grammar is not sufficient, and this leads to give more importance to vocabulary. Thornburry (2002) states that teaching words is a crucial aspect in learning a language as languages are based on words. It is almost impossible to learn a language without words; even communication between human beings is based on words. Both teachers and students agree that acquisition of the vocabulary is a central factor in teaching a language.

Based on the researcher's observation toward the Eighth grade students of SMP Swasta of Dharma Bakti 1 Medan in the Academic Year of 2016/2017 VII when they were learning English vocabulary showed that the students sometimes have low expectation of learning so they are not motivated to learn English vocabulary. They have limited vocabulary to comprehend the meanings of the words in the text. They cannot recognize the meaning of each word uttered by their teacher of English. Moreover, the students are still difficult to communicate in English. It makes the students lazy to learn English. The students did not give attention when the teacher was explaining the material in the class. Furthermore, they just kept silent if the teacher asked them a question in English. So, most of students just acquire a few vocabulary. After the class was over the writer interviewed three students namely KS, RS, and JT. The students said that they often felt afraid of learning English because they did not have enough understanding of the meanings of English words.

The researcher interviewed Mr. ST, the teacher of English at SMP Swasta Dharma Bakti Medan about the students' vocabulary mastery. He said that some of students still had less vocabulary. The students then became passive students in the classroom. The students were not able to catch the point of knowledge which was delivered by the teacher. The writer also interviewed Mr. ST about the Minimal Criterion Mastery (Kriteria Ketuntasan Minimal $(K K M))$. He said that KKM of English is 70, but some of students cannot get value 70. So, to get the KKM the teacher usually gives additional score.

The researcher is interested in trying to give a probable solution by changing the technique of teaching in the classroom. One of the activities of teaching and learning vocabulary which is believed to be the most effective is through games. It has been shown that it has advantages and effectiveness in learning vocabulary in various ways. First, games make relaxation and fun for students, thus games help them learn and retain new words more easily. Second, games usually involve friendly competition and they keep learners interested and motivated. And the third, vocabulary games make real world context into the classroom.

Hurwitz (1969:13) states that games awaken the students eagerness to learn, to think, to create, to listen, and to express their ideas. So, the lesson will be more absorbed by the students and they are involved in the activities directly because games give pleasant variation in learning. One of the games for the students to study English is crossword puzzle game. Crossword puzzle game has been beneficially used in teaching learning process.

A crossword puzzle game is a game in which words have to be fitted across and downwards into spaces with number in a square diagram, the words are found by solving clues. According to Betridge (1984:396) crossword puzzle game can be effective tool in the students' acquisition of vocabulary and allow for meaningful, motivating and relaxing atmosphere that give the students opportunity to improve their vocabulary. Crossword puzzle game can motivate students in studying English and it is suitable for every level of learners. Crossword puzzle game covers several skills in learning English such as vocabulary, reasoning and spelling. By using crossword puzzle game, it is expected that the students will get many new words and enjoy the word game while they are studying the vocabulary. Another benefit of

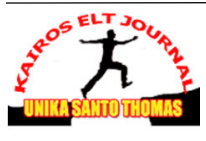


KAIROS ELT JOURNAL, Vol. 2, No. 2, August 2018

Copyright@2018, ISSN: 2580-4278

using crossword puzzle game is to encourage the students to search for new words to improve their vocabulary and also motivate them to learn more seriously.

Related researches had been done several times in different aspect of language vocabulary strategies. The first research has been done by Majaga, et.al (2013) entitled "Improving Vocabulary Mastery of the Eighth Grade Students through Crossword Puzzle". In their journal stated that the use of crossword puzzle can improve the vocabulary mastery of the eighth grade students. The second research has been done by Rosnelly (2010) entitled "The Use of Crossword Puzzle to Improve Students' Vocabulary". In her Sarjana's thesis stated that the use of crossword puzzle is effective to improve students' vocabulary. The third research has been done by Widyasari (2010) entitled "The Use of Crossword Puzzle to Improve Vocabulary Mastery in the First Year of MA AL Bidiyah Candi Bandungan". In her Sarjana's thesis showed that the crossword puzzle could effectively improve students' learning motivation and their vocabulary mastery. Therefore the researcher wants to apply the same technique to teach vocabulary to the eighth grade students of SMP Swasta Dharma Bakti Medan. The writer wants to improve students' vocabulary mastery through crossword puzzle game.

From the statements above, it is summarized that crossword puzzle game is one of alternative and effective techniques that can be applied to improve the students' vocabulary mastery. Based of the background of the study, the researcher is interested in conducting a research entitled "Improving Students' Vocabulary Mastery through Crossword Puzzle Game to the eighth Grade Students of SMP Swasta Dharma Bakti Medan".

\section{REVIEW OF LITERATURE Vocabulary}

Vocabulary is one of the components and supporting elements to the mastery of four language skill namely listening, speaking, reading, and writing. The role of vocabulary cannot be ignored in learning English in order to comprehend the target language. There are some definitions of vocabulary proposed by some experts.

According to Hatch and Brown (1995) the term of vocabulary refers to a list or set of words of a particular language or words that individual speakers of language might use. In other words, a fluent speaker must have an adequate vocabulary to support his speaking. From the definition, it is concluded that vocabulary is a set/list of words of a particular language including single words, compound words and idioms that individual speakers of a language might use.

There are essential steps of learning vocabulary according to Hatch and Brown (1995) namely: 1) Having source for encountering new words, 2) Getting a clear image for the form of new words, 3) Learning the meaning of new words, 4) Making a strong memory connection between the form and the meaning of the words, and 5) Using the words. These steps are supposed to be for adult learners in learning vocabulary. It is different from teaching vocabulary to children. Children are fond of games or playing. Therefore, teacher should choose the appropriate technique to teach vocabulary to children.

\section{Vocabulary Mastery}

The vocabulary mastery is one of the important things in learning a new language. There are some theories about the definition of the vocabulary mastery. According to Hatch and Brown (1995) vocabulary mastery refers to the great skill in processing words of language, it is an individual achievement and possession. The success in widening the vocabulary mastery requires their own motivation and interest of a language on the words. Thus it is concluded that the vocabulary mastery is someone's ability to know and understand about words and they can 
KAIROS ELT JOURNAL, Vol. 2, No. 2, August 2018

Copyright $\odot 2018$, ISSN: 2580-4278

use those words in communication. In this study, the vocabulary mastery refers to the students' understanding of the word meaning and the ability of spelling the word correctly.

\section{Teaching Vocabulary}

Words are essential to communication. Little children learn to speak in isolated words and then in chains of nouns and verbs. We expect students of a second language, however, to control grammatical features of that language as well as its vocabulary. Regardless of the specific target language and the conditions of instruction, vocabulary is an important factor in all language teaching. Students must continually be learning words as they learn structure and as they practise the sound system. Learning vocabulary of course must be according to level of age and ability of the students.

According to Nation (in Nunan 2003:135), there are parts of the course deliberately set aside for vocabulary development, namely: (1) Focus on the most useful vocabulary. First some words can be used in a wide variety of circumstances. Others have much more limited use. For example, the word "help" can be used to ask for help, to describe how people work with others, to describe how knowledge, tools, and materials can make people work more easily easier and so on. Teaching useful vocabulary before less useful vocabulary gives learners the best return for their learning effort. The most useful vocabulary is obviously needed by language learners whether they use the language for listening, speaking, reading and writing or whether they use the language in formal and informal situations. (2) Focus on the vocabulary in appropriate way. The first principle looks at what words to teach and learn. This principle looks at how they should be taught and learned. The most important vocabulary learning strategies include using word part guessing from context, using word cards, and using dictionaries. 3) Give attention to the high frequency words across the four strands of a course. High frequency vocabulary needs to occur in all four strands of a course. It should get deliberate attention through teaching and study and should be met and used in communicating messages in listening, speaking, reading and writing. High frequency vocabulary should also be fluently accessible for receptive and productive use. (4) Encourage learners to reflect and take responsibility for learning. This is an important principle that lies behind choosing and learning, and the learners need to realize that they must be responsible for their own learning. Taking this responsibility requires knowledge of what to learn and the range of options for learning vocabulary, skill in choosing the best options, and the ability to monitor and evaluate progress with those options.

\section{Kinds of Vocabulary}

Hatch and Brown (1995) state that there are two kinds of vocabulary, they are: 1) Receptive vocabulary is words that learners recognize and understand when they are used in context, but which they cannot produce. It is vocabulary that learners recognize when they see or meet in reading text but do not use it in speaking and writing, and 2) Productive vocabulary is the words that the learners understand and can pronounce correctly and use constructively in speaking and writing. It involves what is needed for receptive vocabulary plus the ability to speak or write at the appropriate time. Therefore, productive vocabulary can be addressed as an active process because the learners can produce the words to express their thoughts.

In fact, these two kinds of vocabulary are faced by the learners with different frequency. Productive vocabulary is more often met than the receptive one.

\section{Games}

Games are interesting to teach vocabulary. Thus the teacher should provide appropriate games to teach English vocabularies. Playing game can motivate the students in the English learning. It also makes the learning process become more challenging.

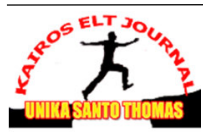


KAIROS ELT JOURNAL, Vol. 2, No. 2, August 2018

Copyright $\odot 2018$, ISSN: 2580-4278

Ohoiwutun (in Majaga, et.al, 2013:3) states that using games, song, quiz and poems in teaching can make the students enjoy. In addition, Napa (in Majaga, et.al, 2013:3) states that the purpose of game is of course to make the material more enjoyable, interesting, and challenging. Both of above statements emphasize that games can be useful in teaching vocabulary, and help students improve their vocabulary without feeling bored and unhappy. Games can be considered useful and effective tools that may be applied in vocabulary classes. The use of game in teaching vocabulary is a way to make lesson more interesting, enjoyable and effective.

\section{Crossword Puzzle Game}

According to Wright, et.al (1997:211) the vocabulary games are divided into 13 types. They are: 1) picture game, 2) psychology of games, 3) magic tricks, 4) caring and sharing games, 5) card and board games, 6) word game/crossword puzzle game, 7) true/false, 8) story games, 9) sound games, 10) memory games, 11)question and answer game, 12) guessing and speculating games, and 13) miscellaneous game. One of them is crossword puzzle game. This type of game is quoted because it relates to the research under discussion.

The crossword puzzle game is a kind of game which consists of some grids with certain arrangement and some clues. The grids are arranged based on the number other letter of each clue answer both vertically or horizontally.

According to Adenan (in Nunan 2013:23), puzzles and games are obvious types of self motivating activity which are interesting and challenging to teach language. Crossword puzzle game can be given by the teacher in order to make the students interested in studying English vocabularies.

The researcher chose crossword puzzle game in this research because it is one of interesting games which makes the students interested in vocabulary learning. Franklin, et.al (2003:80) also state that crossword puzzle game can be significant to increase the students' motivation and the students interest in the topic of learning. The crossword puzzle game gives the students chances to improve their vocabulary.

By applying crossword puzzle games in teaching vocabulary, the students will be entertained. This game also stimulates the students to think what words are appropriate to fill in the blank boxes, affects the students psychologically and makes the teaching learning process more enjoyable, interesting and challenging.

\section{The Procedures Using Crossword Puzzle Game in Vocabulary Teaching}

The teacher can create or use a simple and easy crossword puzzle game that is suitable with students' ability and the teacher should select the words that will be used in crossword puzzle game. It will make the students enjoy answering crossword puzzle game clues.

The procedures of using crossword puzzle game in vocabulary teaching are as the following: 1) The teacher of English explains the crossword puzzle game to the students, 2) The teacher of English asks the students to fill the crossword puzzle individually with a deadline that will be given before the students do the crossword puzzle game, 3) The teacher of English asks the students to exchange their work with their friends, 4) The teacher of English discusses with the students about the correct answer of the crossword puzzle game. The English teacher collects the students' work, and 5) Discussing the correct answers.

The following figure is the example of crossword puzzle game. 


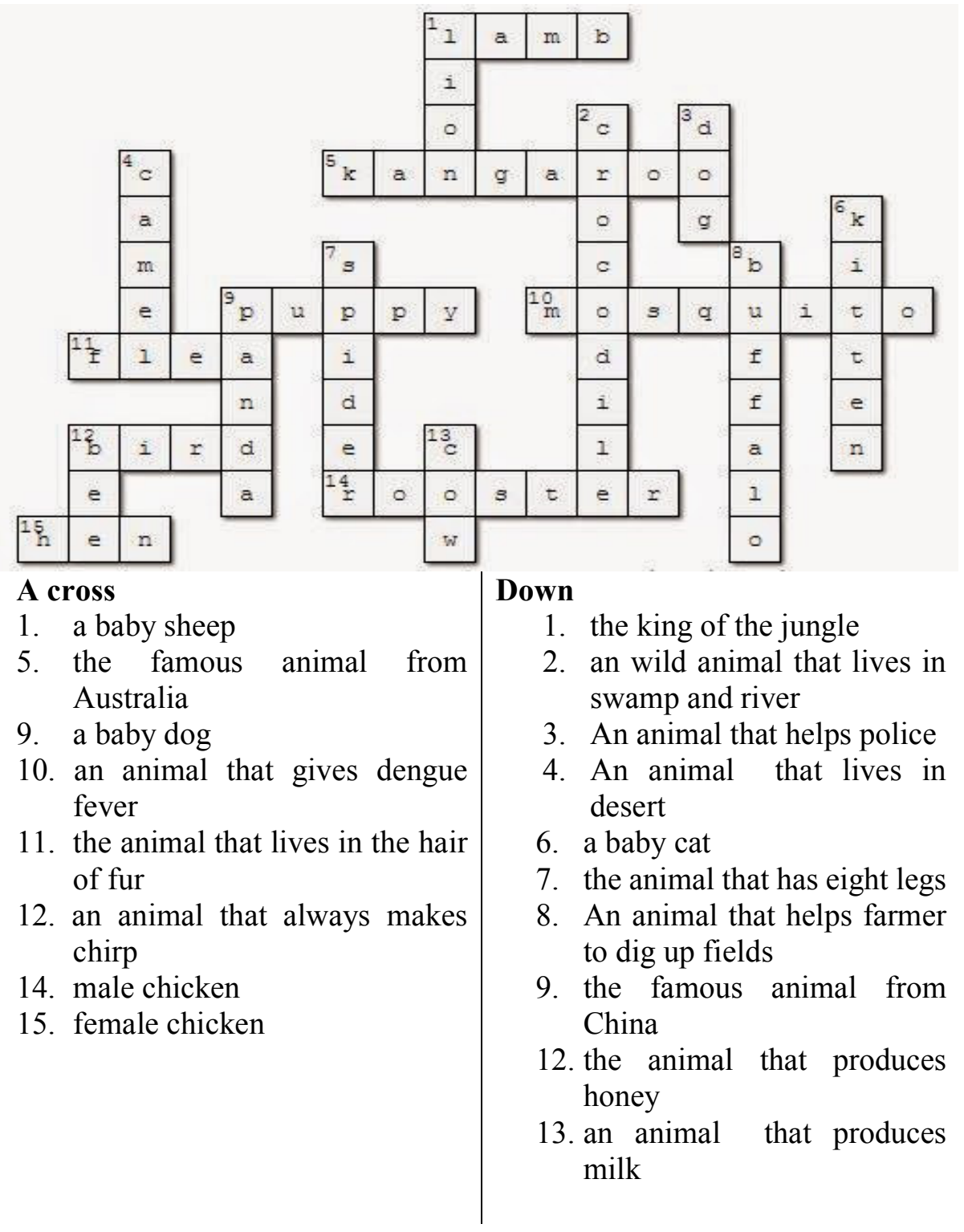

Figure 1. Example of Crossword Puzzle Game Animal

\section{The Advantages of Using Crossword Puzzle game}

Teaching through such as crossword puzzle game is an effective game to teach vocabulary in the classroom. There are many advantages of using crossword puzzle game in the classroom. They are: 1) Crossword puzzle game is fun and students like to play it. Through game, students discover, and interact in their environment, 2) Crossword puzzle game adds variations to a lesson and increases motivation by proving a plausible incentive to use the target language, 3) Crossword puzzle game makes the foreign language immediately useful to the students. It brings the target language to life, 4) Crossword puzzle game makes the reasons for speaking plausible even to reluctant students, 5) Through playing crossword puzzle game, students can learn English the way students learn their mother tongue without being aware they are studying without stress, 6) Even shy students can participate positively, and 7) Crossword puzzle game trains the students on doing the task, particularly in recalling the students' English vocabulary.

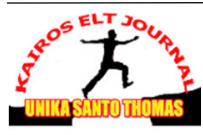


KAIROS ELT JOURNAL, Vol. 2, No. 2, August 2018

Copyright $\odot 2018$, ISSN: 2580-4278

Considering this case, the teacher needs an extra effort to remind the lost vocabulary and to give the students the new vocabulary.

\section{RESEARCH METHOD}

In this research, the writer will apply classroom action research method. Classroom action research begins with a question or questions about classroom experiences, issues, or challenges. It is a reflective process which helps teachers explore and examine aspects of teaching and learning and take action to change and improve the students' achievement in teaching learning process. Metteal (2001:7) states that Classroom Action Research (CAR) is a method of finding out what works best in your own classroom so that you can improve student learning. The goal of Classroom Action Research (CAR) is to improve your own teaching in your own classroom.

According to Mills (2000:6) action research is any systematic inquiry conducted by teachers, researchers, principals, school counselors, or other stakeholders in teaching learning environment to gather information about the ways how their particular school operates, how they teach, and how well their students learn. From the definition above, the researcher concludes that classroom action research is a teaching research to find out the attitude of the students toward the technique being implemented, and the result of implementing technique in teaching learning process.

In this classroom action research, the researcher will collect the data by using qualitative and quantitative methods. Wallace (1978:38) defines that qualitative method is used to describe data which cannot be counted or measured in objective way, while quantitative method is broadly used to describe what can be counted or measured.

\section{DATA ANALYSIS}

The data in this research consisted of qualitative and quantitative .The qualitative data were taken from diary notes and the observation sheet. They were presented below

\section{The Qualitative Data}

The elaboration of qualitative data are follows:

\section{Diary Notes}

Meeting I: Pre-test Thursday, 28 $^{\text {th }}$ September 2016, 11, 45 - 12.25 hours

It is the first meeting the researcher and the eighth grade students of SMP Swasta Dharma Bakti are accompanied by Mr AM (the English teacher at the school). The researcher introduced herself and explained the purpose of her coming to conduct a researcher for her thesis. The students welcomed kindly and they were very enthusiastic. The first meeting, the researcher told to the students to do the test (pretest) before the treatment was conducted for the next meeting. The test was 30 items in multiple choices and was carried out for 45 minutes. During the test the students seemed very difficult to do the test because they did not have good preparation. They really surprised when the researcher gave a test for them and prohibited them from reading the dictionary and working cooperatively. Some students were busy to do other activities, made noise and did not do the test seriously. When the time was up, the researcher collected and corrected it at home. Before the leaving classroom the researcher asked the students to pray and then left the classroom.

\section{Meeting II: Cycle I, 30 ${ }^{\text {th }}$ September 2016, Friday $07.15-09.25$ hours}

The second meeting was the beginning of the cycle I. The researcher entered the class and directly greeted the students. The researcher checked the students' attendance list. Then she introduced the model of presentation in studying vocabulary by using crossword puzzle. The teacher told the students about the topic that day. The topic is about animal, and then the

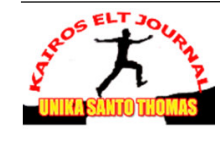


teacher asked to the students about animal. However, most of students just keep silent. Suddenly one student answered that animal is hewan. After that the researcher taught the kinds of the animal. She wrote the kinds of animal on the whiteboard then the researcher started reading and pronouncing the word the students followed after her. During the teaching learning process, the students gave good response. The next lesson was about vocabulary by using a simple crossword puzzle. The teacher asked to the students whether the students know crosswords puzzle. Then, the teacher explained to the students that crossword puzzle is TTS (Teka Teki Silang) and how to do that crosswords puzzle. The situation in class is conducive while the researcher distributed a copy of simple crossword puzzles just 5 items to each of them and did the crossword on the teacher's guidance. Moreover, all of them were so enthusiastic when they are asked to do exercise although they were confused and did not know what should be done. Before closing the class, the researcher concluded the lesson and then closed the class and before leaving the class gave greeting to the students.

\section{Meeting III: Cycle I, October $3^{\text {rd }}$ Monday 2016, 09, $30-10.25$ hours}

In this meeting, the researcher did the actions like in the second meeting namely asking about their condition and the checking their attendance list. After that, she told to the students that they would continue the lesson about" The parts of the body animal". And then she explained the material. After that she asked to the students whether the students still remember how to do crossword puzzle game. Most of students answer the teacher's question that they are still remembering. Next activity the researcher was introducing the vocabulary by using crossword puzzle. She made 5 groups and gave dictionary to each group. Then the researcher read the rules of the crossword puzzle. In this activity every group answered the crossword puzzle. If a group made a mistake, then chance would give to the next group. Since the researcher wanted to encourage all of the students to answer crossword puzzle, every student in groups had to answer the question. Every member could answer the question. The researcher also announced that all the students expected to take notes all word because those words be material of the vocabulary test in the following meeting. Every student was active in the group, some students took notes of the words and others tried to memorize the word. Time was up, the researcher concluded the lesson. Before leaving the class, she closed the meeting and gave greeting to the students.

\section{Meeting IV: Cycle, October $5^{\text {th }}$ Thursday 2016, 10.45 -11.25 hours}

The fourth meeting was the end of the cycle I, the researcher entered the class, and checked attendance list and the researcher and the students continued the lesson namely reviewed the lesson in the meeting one and two in the cycle 1. The researcher reviewed the material. In this meeting the students were excited. They still paid attention to the lesson but sometime they were so noisy and chatted with their friends. After finishing the lesson, she asked the students to close their book and did the test (test after cycle 1), the test was the same test as the pretest and was carried out 45 minutes. They were still confuse when doing the test and asked the researcher some words which they did not understand. When the time was up the researcher collected their work to be corrected at home. Before leaving the classroom the researcher asked the students to pray and then left the classroom.

\section{Meeting V: Cycle II, October $7^{\text {th }}$ Friday2016, 07.15 - 9.15 hours}

In this meeting the researcher entered the class, and checked attendance list the researcher evaluated the previous test and the researcher gave the correct answer. After that she explained the material about the wild animal. The researcher did the brainstorming before starting the lesson. In this meeting the situation in the class was not crowded anymore and they felt more enjoyable during the teaching learning process. At this meeting the researcher

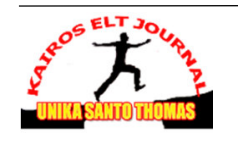


KAIROS ELT JOURNAL, Vol. 2, No. 2, August 2018

Copyright $\odot 2018$, ISSN: 2580-4278

provided 15 items of crossword puzzle and the researcher divided the students into five groups to answer the crossword puzzle and then the researcher contributed to the students. Students' participations in this meeting more increased than the previous meeting. They looked enthusiastically the exercise each groups have one dictionary so that they more easy to answered the exercise. In this meeting each group getting better then in cycle1. Before leaving the class, the students prayed

\section{Meeting VI: Cycle II, October $8^{\text {th }}$ Monday 2016, 07.15 - 9.25 hours}

At the sixth meeting the researcher entered the class, and checked attendance list. The topic was going to be studied "The parts of the body animal". Before starting the lesson, the researcher asked the students about the parts of the body of animal. They knew several parts of the body of animal such feather mouth, eye, head, etc. and then researcher explained the material. They look more enjoyable and enthusiastically during the learning process. After that the researcher tested them again whether they memorized the words which had been. Next activity the researcher distributed vocabulary by using crossword puzzle. She made 5 groups and gave dictionary to each group. Then the researcher read the rules of the crossword puzzle. In this activity every group answered the crossword puzzle. If a group made a mistake, then chance would give to the next group. Since the researcher wanted to encourage all of the students to answer crossword puzzle, every student in groups had to answer the question. Every member could answer the question. The researcher also announced that all the students expected to take notes all word because those words be material of the vocabulary test in the following meeting. Every student was active in the group, some students took notes of the words and others tried to memorize the word. Time was up, the researcher concluded the lesson. Before leaving the class, she closed the meeting and gave greeting to the students.

\section{Meeting VII: Cycle II, October $10^{\text {th }}$ Thursday 2016, 07.15 - 8.25 hours}

In this meeting was the end of the cycle 2 the researcher entered the class, and checked attendance list. After that the researcher invited the students to sing a song. The song was "BI-N-G-O", the students were so happy to sing this song. They spelled the words of bingo enthusiastically. This activity was done by the researcher to make the classroom relax and enjoy. After singing a song the researcher continued tried to review all topics in the cycle 2 . And then the researcher made 30 items vocabulary test and then the researcher distributed the test to each student. During they did test they were so excited, more serious and less noisy. After that the researcher asked the students one by one to answer the test. Some of them raised their hand to do their test in front of class. This meeting was better. Before closing the class, the researcher concluded the lesson and then closed the class and gave greeting to the students. Cycle 2 was done well.

\section{Meeting VIII: Cycle II, $14^{\text {nd }}$ Friday 2016, 07.15 - 9.15 hours}

This was the last meeting, so the researcher had to ensure if the students vocabulary mastery improve or not by giving post-test. Before giving the post-test, as usual the researcher greeted the students and checked their attendance list. Next, the researcher told to the students that they would be given test. And then the researcher distributed vocabulary test to each student. The test was the same as the pretest. It was 30 items and carried out for 45 minutes. During the test the students exited to answer the crossword puzzle. When they had finished, the researcher collected their work to be corrected at home. The researcher believed that the students' score would get improved. The research was done well in eight meetings.

The diary notes showed that the teaching learning process was carried out well. The students were very active, excited and interested in learning vocabulary by using crossword puzzle, even 
KAIROS ELT JOURNAL, Vol. 2, No. 2, August 2018

Copyright $\odot 2018$, ISSN: 2580-4278

though sometimes the situation in the classroom was noisy because the students always asked the researcher about the difficult words.

\section{Observation Sheet}

The observation sheet was made by researcher to be checked by the teacher who observed the teaching learning process in the cycle 1 and cycle 2 .

We can see the observation below.

Table 1. Observation Sheet Cycle I

\begin{tabular}{|c|c|c|c|}
\hline \multirow[b]{2}{*}{ Focus } & \multirow[b]{2}{*}{ Description } & \multicolumn{2}{|c|}{ Meeting I } \\
\hline & & Yes & No \\
\hline TEACHER & $\begin{array}{l}\text { - The teacher comes to the class on time } \\
\text { - The teacher greets the students } \\
\text { - The teacher does brain storming to } \\
\text { introduce the topic } \\
\text { - The teacher explains the material to the } \\
\text { students } \\
\text { - The teacher uses media in presenting the } \\
\text { material } \\
\text { - The teacher motivates the students in } \\
\text { learning } \\
\text { - The teacher gives a chance to the students } \\
\text { - to ask about the lesson } \\
\text { - The teacher concludes the lesson } \\
\text { The teacher leaves the class on time }\end{array}$ & $\begin{array}{l}\sqrt{ } \\
\sqrt{ } \\
\sqrt{ } \\
\sqrt{ } \\
\sqrt{ } \\
\sqrt{ } \\
\sqrt{ } \\
\sqrt{ } \\
\sqrt{ }\end{array}$ & \\
\hline STUDENTS & $\begin{array}{l}\text { - The students listen the teacher's } \\
\text { explanation about the lesson } \\
\text { - The students give participation during the } \\
\text { teaching learning process } \\
\text { - The students ask the teacher about the } \\
\text { unclear lesson } \\
\text { - The students are given the test by teacher }\end{array}$ & $\sqrt{ }$ & $\begin{array}{l}\sqrt{ } \\
\sqrt{ } \\
\sqrt{ }\end{array}$ \\
\hline CONTEXT & $\begin{array}{l}\text { - The classroom is far from crowd } \\
\text { - The classroom is clean and fresh } \\
\text { - The classroom is comfortable }\end{array}$ & & $\begin{array}{l}\sqrt{ } \\
\sqrt{ } \\
\sqrt{ }\end{array}$ \\
\hline
\end{tabular}

Table 2. Observation Sheet Cycle Ii

Give checklist in column Yes or No on your Observation!

\begin{tabular}{|c|c|c|c|}
\hline \multirow[b]{2}{*}{ Focus } & \multirow[b]{2}{*}{ Description } & \multicolumn{2}{|c|}{ Meeting I } \\
\hline & & Yes & No \\
\hline TEACHER & $\begin{array}{l}\text { - The teacher comes to the class on time } \\
\text { - The teacher greets the students } \\
\text { - The teacher does brain storming to introduce } \\
\text { the topic } \\
\text { - The teacher explains the material to the } \\
\text { students } \\
\text { - The teacher uses media in presenting the } \\
\text { material }\end{array}$ & $\begin{array}{l}\sqrt{ } \\
\sqrt{ } \\
\sqrt{ } \\
\sqrt{ } \\
\sqrt{ } \\
\sqrt{ } \\
\sqrt{ } \\
\sqrt{ }\end{array}$ & \\
\hline
\end{tabular}


KAIROS ELT JOURNAL, Vol. 2, No. 2, August 2018

Copyright $\odot 2018$, ISSN: 2580-4278

\begin{tabular}{|c|c|c|}
\hline & $\begin{array}{l}\text { - The teacher motivates the students in } \\
\text { learning } \\
\text { - The teacher gives a chance to the students to } \\
\text { ask about the lesson } \\
\text { - The teacher concludes the lesson } \\
\text { - The teacher leaves the class on time }\end{array}$ & $\sqrt{ }$ \\
\hline STUDENTS & $\begin{array}{l}\text { - The students listen the teacher's explanation } \\
\text { about the lesson } \\
\text { - The students give participation during the } \\
\text { teaching learning process } \\
\text { - The students ask the teacher about the unclear } \\
\text { lesson } \\
\text { - The students are given the test by teacher }\end{array}$ & $\begin{array}{l}\sqrt{ } \\
\sqrt{ }\end{array}$ \\
\hline CONTEXT & $\begin{array}{l}\text { - The classroom is far from crowd } \\
\text { - The classroom is clean and fresh } \\
\text { - The classroom is comfortable }\end{array}$ & $\begin{array}{l}\sqrt{ } \\
\sqrt{ } \\
\sqrt{ }\end{array}$ \\
\hline
\end{tabular}

The table 1 and 2 showed the observation of the researcher which was focused on the situation of teaching learning process. We could see that there was an improvement from cycle 1 in to cycle 2 . The students did not participate, did not ask the unclear lesson in cycle 1 . It happened because the researcher was a the new comer to them so that they were just quite and follow what the researcher asked to do.

In cycle 2, all things became different. The students did their part well. They tried to be more active during the teaching learning process. In cycle 2 the students were more enjoyable, comfortable and give more participation during learning process.

\section{The Quantitative Data}

The quantitative data was taken from the results of two cycles, namely cycle 1 and cycle 12 which were conducted in eight meetings. It meant that there were two vocabulary tests in two cycles. Besides, a pretest was also administered to the students before the treatment and posttest after the treatment. In the middle, there was a formative test after cycle 1 . It could be seen that the mean score of each test administered to the students.

Table 3. The Mean Score of the Students Test

\begin{tabular}{|l|l|}
\hline Test & Mean score \\
\hline Pretest & 36.71 \\
\hline Test after cycle 1 & 64.10 \\
\hline Post test end program & 78.48 \\
\hline
\end{tabular}

From the data above, we can see mean of the students' score in vocabulary test kept increasing. In pretest the mean was only 36.71 , in cycle 1 the mean was improved to 64.10 , and then in cycle 2 the mean became 78.48. It was proved that the students' vocabulary score was improved after the students were taught through crossword puzzle.

\section{The Scoring Test}

The score improvement could be seen in below.

Table 4. Data Frequency Distribution for Score Pre-Test 
KAIROS ELT JOURNAL, Vol. 2, No. 2, August 2018

Copyright $C 2018$, ISSN: 2580-4278

\begin{tabular}{|l|l|l|l|l|l|}
\hline No & $\begin{array}{l}\text { Score } \\
\text { Interval }\end{array}$ & Frequency & Percentage & The Quality & Category \\
\hline 1 & $85-100$ & 0 & 0.00 & A & $\begin{array}{l}\text { VERY } \\
\text { HIGH }\end{array}$ \\
\hline 2 & $70-84$ & 0 & 0.00 & B & HIGH \\
\hline 3 & $60-69$ & 0 & 0.00 & C & AVERAGE \\
\hline 4 & $50-59$ & 1 students & 4.76 & D & LOW \\
\hline 5 & $0-49$ & 20 students & 95.24 & E & VERY LOW \\
\hline & Total & $\mathbf{2 1}$ students & $\mathbf{1 0 0}$ & & \\
\hline
\end{tabular}

Based on the table of the pre-test score it could be seen that there was no students who got $85-100$, it was $0 \%$. 0 students got score $70-84$ it was $0 \%$. Score $60-69$ was gotten by 0 students, it was $0 \%$. One student get score $50-59$, it was $4.76 \%$ and 20 students got score 0 49 , it was $95.24 \%$. The conclusion of the table was that in the pretest, most of the students got very low score, namely 20 students or it was about $95.24 \%$. This cycle test got very low score.

Table 5. Frequency Distribution for Score Post-Test 1

\begin{tabular}{|l|l|l|l|l|l|}
\hline No & Score interval & Frequency & Percentage & The Quality & Category \\
\hline 1 & $85-100$ & 0 & 0.00 & A & VERY HIGH \\
\hline 2 & $70-84$ & 10 & 47.62 & B & HIGH \\
\hline 3 & $60-69$ & 3 & 14.29 & C & AVERAGE \\
\hline 4 & $50-59$ & 7 & 33.33 & D & LOW \\
\hline 5 & $0-49$ & 1 & 4.76 & E & VERY LOW \\
\hline & Total & $\mathbf{2 1}$ & $\mathbf{1 0 0}$ & & \\
\hline
\end{tabular}

Based on the table of the post-test cycle 1 score it could be seen that there was no students who got $85-100$, it was $0 \%$. And 10 students got score $70-84$ it was $47.62 \%$. Score $60-$ 69 was gotten by 3 students, it was $14.29 \% .7$ students get score $50-59$, it was $33.33 \%$. 1 student got score $0-49$, it was $4.7 \%$. The conclusion of the table was that in the posttest of cycle 1 , most of the students got high score, namely 10 students or it was about $47.62 \%$. This cycle test high score.

Table 6. Frequency Distribution for Score Post-Test 2

\begin{tabular}{|l|l|l|l|l|l|}
\hline No & Score Interval & Frequency & Percentage & $\begin{array}{l}\text { The } \\
\text { Quality }\end{array}$ & Category \\
\hline 1 & $85-100$ & 4 Students & 19.05 & A & VERY HIGH \\
\hline 2 & $70-84$ & 14 students & 66.67 & B & HIGH \\
\hline 3 & $60-69$ & 3 & 14.28 & C & AVERAGE \\
\hline 4 & $50-59$ & 0 & 0 & D & LOW \\
\hline 5 & $0-49$ & 0 & 0 & E & VERY LOW \\
\hline & Total & $\mathbf{2 1}$ & $\mathbf{1 0 0}$ & & \\
\hline
\end{tabular}

Based on the table of the posttest score it could be seen that there was 4 students who got $85-100$, it was $19.5 \%$. 14 students got score $70-84$ it was $66.67 \%$. Score $60-69$ was by 3 students, it was $14.29 \%$. No students get score $50-59$, it was $0 \%$, neither did for score $0-49$. We can make a conclusion that in the post-test cycle 2 the students' vocabulary improved. Most of the students got high score, namely 14 students or it was $66.67 \%$. It was better than the pretest which was very low, and it was better than cycle 1 . It can be seen that the students' score got higher than their previous score. Perhaps, this was due to the crossword puzzle game.

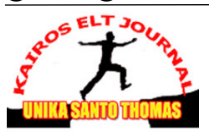


KAIROS ELT JOURNAL, Vol. 2, No. 2, August 2018

Copyright $\odot 2018$, ISSN: 2580-4278

Increasing the students' score in learning vocabulary through crossword puzzle could be seen from the mean of the students in each test. To find out the mean in each test, the researcher applied this following formula:

$$
\mathrm{X}=\frac{\sum X}{N} \times 100 \%
$$

Where:

$X=$ The mean of the students' score

$\sum \mathrm{x}=$ The total score of the students

$\mathrm{N}=$ The number of the students

a. In the pre-test, the total score of the students was 771.00 , and the number of the students was 43 . The mean is $\mathrm{X}=\frac{771}{21} \times 100 \%=36.71$

b. In the post-test cycle 1, the total score of the students was 1346, and the number of the students was 43 . The mean is $\mathrm{X}=\frac{1346}{21} \times 100 \%=64,10$

c. In the post-test cycle 2, the total score of the students was 1648, and the number of the students was 43 . The mean is $\mathrm{X}=\frac{1648}{21} \times 100 \%=78,48$

To analyze the students score the improvement of the students score was counted by using this following formula:

$$
P=\frac{R}{T} \times 100 \%
$$

Where:

$\mathrm{P}=$ The percentage of the students who get 70

$\mathrm{R}=$ The number of the students who get 70 up

$\mathrm{T}=$ Total number of the students

The percentage of the students' vocabulary pre-test score, formative test of cycle 1 and postest end program could be seen as follow:
a. $\mathrm{P}=\frac{0}{21} x 100 \%=0 \%$
b. $\mathrm{P}=\frac{10}{21} x 100 \%=47,62 \%$
c. $\mathrm{P}=\frac{18}{21} x 100 \%=85,72 \%$

Table 7. The Percentage of the Students got Up 70

\begin{tabular}{|l|l|l|}
\hline Test & Percentage & Number of the students \\
\hline Pre-test & $0 \%$ & 0 \\
\hline Formative cycle 1 & $47,62 \%$ & 10 \\
\hline Post-test & $85,72 \%$ & 11 \\
\hline
\end{tabular}

The result showed the improvement of the students score from the first test (pre-test) to the second test (post-test cycle 1) and test to the third test (post-test end program). When the first (pre-test) was administered to the students, there is no student who got the score above 70 . In the second test (post-test cycle 1), there were $47.62 \%$ who or 10 students who got score above 70. It could be seen that from the first to the second test (cycle 1) there was improvement $47.62 \%$. In the third test (post-test end program), there were $85,72 \%$ or 18 students who got score above. It meant that there was improvement of the students vocabulary score from the pre-test up to the last post-test. We could compare the pretest score and the post-test namely $0 \%$ become $85.72 \%$. It could be concluded that there was $85.72 \%$ improvement between pretest and post-test. So that the application of crossword puzzle in improving the students' vocabulary worked well.

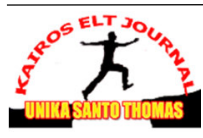


KAIROS ELT JOURNAL, Vol. 2, No. 2, August 2018

Copyright $\odot 2018$, ISSN: 2580-4278

\section{Research Findings}

Research findings were taken from the quantitative and qualitative data. The quantitative data were taken from the students' score in pretest and post-test score. The result of the posttest score was higher than pretest score. We could answer the first problem of the research that the vocabulary mastery of the students improved after having been taught through crossword puzzle.

The qualitative data were taken from the diary notes and observation sheet which were shown in appendix. We could see that the students felt excited in learning vocabulary through crossword puzzle. it also could be seen from the students score which improved from $0 \%$ to $85.72 \%$. It could be concluded that the students' score increased because the students enjoyed and felt interested in learning vocabulary through crossword puzzle.

\section{Discussion}

Crossword puzzle was applied to improve students' vocabulary mastery. The crossword puzzle was one many game that could make the students easier in learning English especially in vocabulary mastery. This research proved effectiveness of applying crossword puzzle. It was shown in table 4.3, the mean of each test, the pre-test mean was 36,71, the post-test cycle 1 mean was 64,10 and the pos-test end program was 78,48. There was improvement between the pre-test and post-test it was $0 \%$ to $85,72 \%$.

It could be also seen from the table 4.7 students' score in the last test (post-test) was significantly higher than the first test (pre-test). In the post-test cycle 2, from 21 student who followed the test, there were 18 students who got score above 70 . In the post-test cycle 1 , there were 10 students who got score above 70 and in the pre-test, there was no student who got score above 70. It can be concluded that the use of crossword puzzle in improving students' vocabulary mastery was effective to the students in junior high school. Crossword puzzle could help the students enjoy in learning so that they do not get bored during the teaching learning process. Crossword puzzle also helps the teacher in teaching vocabulary to the students so that the goals of teaching learning can achieved well.

But in applying this game, the writer faced some problems. Some problems that faced by the writer for example, when the writer tried to approach some students, the other students made noise. The next problem was the background of their knowledge. Although every students had different knowledge, but almost all of them were not clever.

\section{CONCLUSIONS}

The conclusion of this research is presented according to the data have been analyzed in the previous chapter. From all data analysis about using crossword puzzle to improve students' vocabulary (A Classroom Action Research to the eighth grade students of SMP Swasta Dharma Bakti Medan in Academic Year of 2016/2017), it can be concluded that:

1. The students' vocabulary mastery improved. It is proved by the result of the test, the pretest score was 36,71 become 78,48 after being tested in post-test. The students' achievement is satisfied enough. It can be said that the use of crossword puzzle makes the students familiar with the new words.

2. The students are interested in learning improved. It can be seen from the diary notes and observation sheet. The students are interested in learning during the teaching learning process. Through the use crossword puzzle in each activity, there was improvement of the students' motivations in learning. It could be seen from the post-test score which is higher than the pre-test score. The students' interest in learning English influences their participation in the class. The classroom situation becomes active because they enjoy and they are motivated in teaching learning process.

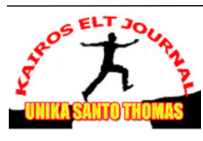




\section{BIBLIOGRAPHY}

Betridge, 1984. Games for Language Learning. $\quad\left(2^{\text {nd }} \quad\right.$ Ed $) . \quad$ Cambridge: Cambridge University Press.

Burns, A, 2010. Doing Action Research in English Language Teaching; A Guide for Practioners. Sydney: Macquaric University.

Franklin, et.al. 2003. "Nontraditional Interventions to Stimulate Discussion". International Journal of Biological Education, 37 (2), 76-82.

Hatch, A., \& Brown, C. 1995. Vocabulary, Semantic, and Language Education. New York: Cambridge University Press.

Hurwittz, A., B. 1969. Games to Improve Your Child's English. New York: Simon Shuster.

Majaga, et.al. 2013. "Improving Vocabulary Mastery of the Eighth Grade Students through Crossword Puzzle”. Journal of English Language Teaching Society (ELTS), 1 (2), 1-14.

Metteal, G. 2001. The What, Why and How of Classroom Action Research. Journal of Scholarship in Teaching and Learning (JoSoTL), 2(1) 6-13.

Mills, Geoffrey E. 2000. A Teacher's Guide to Classroom Research. Buckingman: Open University Press.

Nation, I. S. P. 2003. Vocabulary in Nunan, D. Editor. Practical English Language Teaching. Cambridge: Cambridge University Press.

Nunan, R. 2013. "The Effect of Using Crossword Puzzle on Vocabulary Achievement". Journal of Teaching and Education, 2 (2) 23-32.

Rosnelly. 2010. The Use of Crossword Puzzle to Improve Students' Vocabulary. Sarjana's Thesis, Teacher Training and Education Faculty: Islamic University of Riau. Unpublished.

Thornburry, S. (2002). How to Teach Vocabulary. Cambridge: Cambridge University Press.

Wallace, Michael J. 1978. Action Research for Language Teachers. Cambridge: Cambridge University Press.

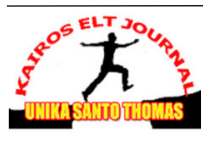

